\title{
Is Underpricing an Appropriate Proxy for Studying IPO Certification?
}

\author{
Mike Hopkins ${ }^{1} \&$ Donald G. Ross ${ }^{1}$ \\ ${ }^{1}$ School of Business, Australian Catholic University, North Sydney, Australia \\ Correspondence: Mike Hopkins, School of Business, Australian Catholic University, North Sydney, Australia. \\ Tel: 61-2-9739-2354. E-mail: mike.hopkins@acu.edu.au
}

Received: January 30, 2014

Accepted: March 7, 2014

Online Published: April 25, 2014

doi:10.5539/ijef.v6n5p117

URL: http://dx.doi.org/10.5539/ijef.v6n5p117

\begin{abstract}
The dominant technique used to evidence certification effects at IPO is to employ the degree of underpricing as a proxy for certification. We investigate the appropriateness of this proxy in the context of private equity backed IPOs. Our results reveal an incongruence between certification by the vendor and expectations of underpricing. We also find expectations of underpricing are driven by reduced informational asymmetries between the vendor and the vendor's broker rather than between the vendor and the market. Our conclusion is that underpricing is too noisy a variable to be a reliable proxy for certification in this context.
\end{abstract}

Keywords: certification, IPO, private equity, reputations, private equity added value, underpricing

\section{Introduction}

Many studies have investigated certification effects at IPO. These have included the certification effects of underwriters (e.g., Carter, Dark, \& Singh, 1998; Carter \& Manaster, 1990; Logue, 1973; Tiniç, 1988), private equity firms (e.g., Barry, Muscarella, Peavy, \& Vetsuypens, 1990; Bradley \& Jordan, 2002; Lee \& Wahal, 2004; Megginson \& Weiss, 1991), auditors (e.g., Beatty \& Welch, 1996; Michaely \& Shaw, 1995) and lawyers (Beatty $\&$ Welch, 1996). Common to many of these studies is the use of the level of underpricing as a proxy variable to assess the presence and magnitude of any certification effect. This practice dominates the study of certification effects attributable to private equity firms and has been applied to studies in the US, Europe, Asia and Australasia (e.g., Barry et al., 1990; Bergström, Nilsson, \& Wahlberg, 2006; Bradley \& Jordan, 2002; Da Silva Rosa, Velayuthen, \& Walter, 2003; Franzke, 2003; Hamao, Packer, \& Ritter, 2000; Kraus \& Burghof, 2003; Lee \& Wahal, 2004; Megginson \& Weiss, 1991; Tykvovã \& Walz, 2007; Van Der Geest, \& Van Frederikslust, 2001).

With such common usage, it is perhaps surprising that the use of underpricing in studying certification effects is not more often questioned or investigated. This paper reports the results of a study which investigated the determinants of certification and the appropriateness of using underpricing as a ubiquitous proxy for certification. The study adopted a market perspective using financial analysts as the unit of analysis.

\section{Underpricing as a Proxy for Certification at IPO}

Underpricing at IPO is the practice of setting an initial offer price below that which the market is expected to value the stock immediately following the issue (Francis, Hasan, \& Hu, 2003; Hunt-McCool, Koh, \& Francis, 1996). Underpricing is common and deliberate (Brennan \& Franks, 1997; Hunt-McCool et al., 1996) and explanations for it include: (1) to incentivise investors facing risk from informational asymmetries with issuers and investment bankers, especially for smaller, uninformed investors (Baron, 1982; Ibbotson, 1975; Lee, Taylor, \& Walter, 1999; Logue, 1973; Rock, 1986), (2) to signal quality (Allen \& Faulhaber, 1989), (3) to provide incentives for regular investors to reveal information and intent (Benveniste \& Spindt, 1989), (4) the desire to leave positive perceptions of the IPO process and actors with analysts and investors through early capital gains to increase the attractiveness of follow-on issues, that is longer term, mutually beneficial signalling and reputation building functions (Ibbotson, 1975; Jegadeesh, Weinstein, \& Welch, 1993; Lerner, 1994; Logue, 1973; Neus \& Walz, 2005; Telser, 1980; Welch, 1989), (5) regulation and/or government interference (Ibbotson, 1975; Loughran, Ritter, \& Rydqvist, 1994), (6) collusion (Ibbotson, 1975), (7) to encourage over subscription, thereby facilitating choice in share allocations (Brennan \& Franks, 1997) and (8) to reduce the likelihood of legal action following poorly performing IPOs (Ibbotson, 1975; Tiniç, 1988).

The degree of underpricing has been theorised as being a signal of the quality of a firm (Allen \& Faulhaber, 1989), which is often combined with complementary signalling characteristics, including: (1) the size of offering 
(Gale \& Stiglitz, 1989), (2) the level of retained ownership (Downes \& Heinkel, 1982; Gale \& Stiglitz, 1989; Grinblatt \& Hwang, 1989; Leland \& Pyle, 1977), (3) the value of the firm (Grinblatt \& Hwang, 1989) and (4) the quality of underwriters and/or auditors commissioned for the issue (Titman \& Trueman, 1986).

Reduced underpricing reduces the differential between the issue price and the immediate post issue market price. Reduced underpricing, therefore, impacts the distribution of realised value between pre and post IPO shareholders (How, Izan, \& Monroe, 1995). Numerous empirical studies have identified several factors that are associated with underpricing levels. For example, Logue (1973) and Beatty and Ritter (1986) found that underpricing was lower for larger companies and there is some evidence to support that it is larger for smaller issues (Hanley, 1993; Ritter, 1987), although this finding is not consistent (Tiniç, 1988). Logue (1973) also evidenced that prestigious underwriters were associated with lower underpricing (see also Carter, Dark, \& Singh, 1998; Carter \& Manaster, 1990; Michaely \& Shaw 1995, Tiniç, 1988), Beatty and Ritter (1986) that increased underpricing was associated with greater pre-issue uncertainty, Ritter (1987) that "best effort" issues had greater underpricing than firm commitment issues, Hunt-McCool, Koh \& Francis (1996) that underpricing was higher in "hot" issue markets, Loughran, Ritter and Rydqvist (1994) that underpricing was greater the earlier a fixed price is set and Beatty and Welch (1996) that underpricing was positively related to the number of risk factors cited in the issue prospectus and negatively related to the quality of auditors and lawyers. The Beatty and Welch (1996) study also suggested the general economic environment influenced underpricing and that the 1990s had seen a reversal of the 1980s experience of high quality underwriters being associated with lower underpricing.

Early studies, using data from before the 1990s, on venture capital influence suggested venture capital backed IPOs experienced reduced underpricing (Barry et al., 1990; Megginson \& Weiss, 1991), although Barry et al. (1990) found reduced underpricing only where "quality" venture capitalists and underwriters were involved in the IPO (see also Carter \& Manaster, 1990; Logue, 1973; Spiess \& Pettway, 1997 re-underwriter quality). Factors associated with reduced underpricing include the experience of the principal venture capitalist, the lifespan of the venture capital firm and the length of time the principal venture capitalist has spent on the board of the investee company (Barry et al., 1990). More recent studies, based on data from the 1990s, have generated contradictory results. Francis et al. (2003) found venture capital backed IPOs displayed higher underpricing, attributing this to venture capitalists being associated with higher risk ventures. This finding is supported by studies by Brav and Gompers (2003), Bradley and Jordan (2002) and Lee and Wahal (2004). Both the Bradley and Jordan (2002) and Lee and Wahal (2004) studies analysed data from the 1990s which included the "internet bubble" and their aggregate data was heavily influenced by these later years. Nevertheless, Bradley and Jordan (2002) found venture capital backed IPOs to experience higher underpricing in eight of the ten years studied and Lee and Wahal (2004) found only insignificant evidence of reduced underpricing in periods outside the "bubble" years. Bradley and Jordan (2002) concluded that the high underpricing they evidenced for venture capital backed firms was heavily influenced by industry effects, in particular noting the high representation of technology firms among venture capital investments and their incidence of listing on the NASDAQ. Once these effects were controlled for, they found no significant difference between the underpricing of venture capital backed and non-venture capital backed IPOs. This influence of technology bias was further highlighted by Lee and Wahal (2004) who also evidenced a significant association between higher underpricing and the future flow of capital into venture capital funds adding weight to Gompers's (1996) earlier work on grandstanding. The significance of findings of increased underpricing in these more recent studies has been questioned by Dolvin and Pyles (2006) who, following Habib and Ljungqvist's (2001) consideration of wealth loss rather than raw underpricing, demonstrated that venture capitalist involvement resulted in lower wealth losses to pre-IPO owners, providing renewed support for the presence of a certification effect. They also suggested the quality of venture capitalist was a significant factor in reducing the level of money left on the table and this was achieved through enticing entrepreneurs to retain higher levels of ownership, which offset the increased raw underpricing. Reduced underpricing has also been found in respect of reverse LBOs, that is buyouts that return to public ownership having previously been taken private (Cao \& Lerner, 2009; DeGeorge \& Zeckhauser, 1993; Holthausen \& Larcker, 1996; Muscarella \& Vetsuypens, 1989).

Several studies have evidenced associations between the quality of venture capitalists, auditors, solicitors and underwriters, making it difficult to attribute any certification benefits to any particular actor (Bradley \& Jordan, 2002; Dolvin \& Pyles, 2006; Francis et al., 2003; Krishnan et al., 2009; Lee \& Wahal, 2004; Morsfield \& Tan, 2006; Stein \& Bygrave, 1990). Reverse leverage buyouts, similarly, have been found to be associated with more reputable underwriters (Cao \& Lerner, 2009). However, it is worthy of note that the key early works of Megginson and Weiss (1991) and Barry et al. (1990) were able to control for underwriter quality. Both found a certification effect for venture capitalists after the control. 
The commonly cited certification role posited by Megginson and Weiss (1991) has also been questioned by Habib and Ljunqvist (2001) who, while finding that younger and smaller offerings are riskier and therefore more underpriced in line with Megginson and Weiss (1991), proffered the alternative explanation that this may be because a greater proportion of shares were being sold and therefore greater promotional spend incurred in supporting the sale. The effect of this was to reduce informational asymmetries and consequently the level of underpricing. Their argument was founded on their empirical findings that: (1) underpricing decreases as promotional spend increases, (2) promotional costs increase with the number of shares sold and (3) underpricing decreases with increases in insider selling (see also Bradley \& Jordan, 2002).

Evidence of a certification role extends beyond studies based on underpricing. Jain and Kini (1995) posited that markets recognised the added value of venture capital backing and this was reflected in higher valuations for venture capital backed IPOs. Brau and Fawcett (2006), in a survey of Chief Financial Officers, confirmed a certification role for venture capitalists at IPO. Comparisons of the returns on investment achieved by leading venture capitalists also support conclusions of added value and certification at IPO, that is that higher quality venture capitalists and underwriters are associated with higher returns (Lange et al., 2001; Stein \& Bygrave, 1990), although in both the Stein and Bygrave (1990) and Lange et al. (2001) studies the definition of leading venture capitalist was based on activity volume rather than metrics related to their previous record of successful IPOs or returns. Accordingly, these higher returns could have emerged simply because these leading venture capitalists were in a position to back the best investments rather than because of any specific value adding activities on the part of the venture capitalists. Additional evidence consistent with the existence of a certification effect are the facts that venture capital backed IPOs have been found to be smaller (by market capitalisation) than non-venture capital backed IPOs (Brav \& Gompers, 1997; Francis et al., 2003) and are brought to market earlier (Megginson \& Weiss, 1991).

\section{Research Model and Questions}

The conceptual framework for this study is grounded in theories of resource dependence and exchange (Pfeffer \& Salancik, 1978), agency risk (Jensen \& Meckling, 1976) and informational asymmetry (Akerlof, 1970), including certification theory (Booth \& Smith, 1986).

The model posits three types of resources: network, knowledge and time resources. Network resources derive from the social capital of private equity firms and include their networks and contacts with suppliers, customers and professional advisers including accountants, lawyers, underwriters and industry specialists who can frequently act as consultants or board representatives. The extent and quality of network resources will have a direct influence over a private equity firm's reputation in the market and will influence the performance of the investee company over the course of their relationship depending on the amount of time the private equity firm dedicates to the firm. Knowledge resources derive from the technical, industry and managerial knowledge and experience of the private equity firm and its knowledge and experience of the IPO process. The extent and quality of knowledge resources will have a direct influence over a private equity firm's reputation in the market and will influence the performance of the venture depending on the amount of time the private equity firm dedicates to the investee company. The time resource is, therefore, a critical conduit through which other resources are applied (Balboa \& Marti, 2007; Kanniainen \& Keuschnigg, 2003; Van Osnabrugge \& Robinson, $2001)$ and the amount and frequency of contact with investees has been shown to be positively associated with measures of performance (e.g., Cumming \& Walz, 2009; Gabrielsson \& Huse, 2002; Sapienza, 1992; Sapienza \& Timmons, 1989).

The key inputs hypothesised as contributing to certification are knowledge, network and time resources. These resources are disparate in nature and detailed information on their application to individual cases is impractical to monitor and convey to the market. The inputs have to be operationalised into variables that can be readily conceptualised by research subjects and on which there is likely to be sufficient information available at the IPO to allow subjects to distinguish between lesser and greater degrees of the variable. Accordingly, the variables are defined around information that can reasonably be expected to be included in the offer prospectus, IPO presentations or obtainable from general market intelligence.

The model outlined in Figure 1 theorises on the application of four factors (independent variables) attributable to private equity backed IPOs that would not be applicable to non-private equity backed IPOs, that is that could contribute to a certification role for private equity firm. 


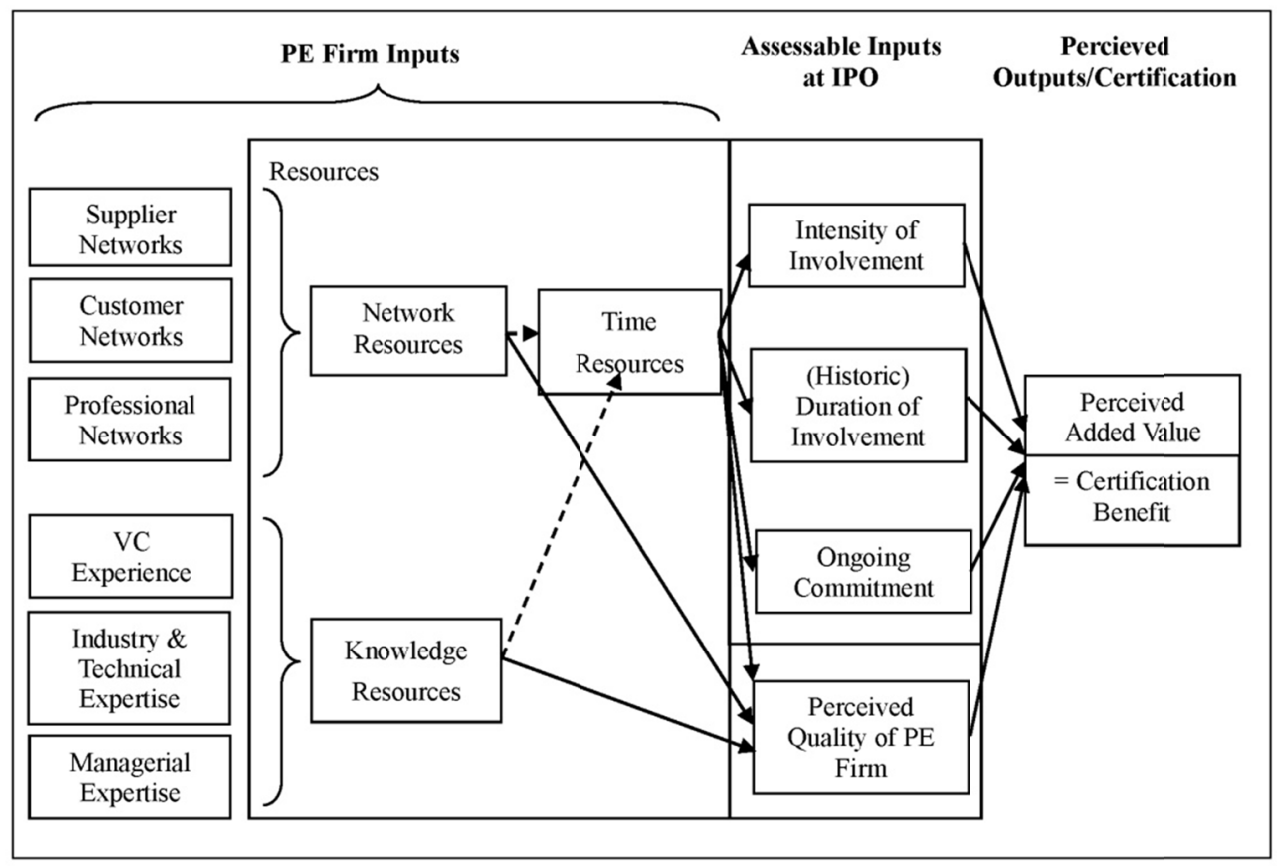

Figure 1. Research model

The four factors hypothesised as influencing private equity firms' certification role are: (1) the intensity of their involvement, (2) the duration of their involvement prior to the IPO, (3) their commitment to ongoing involvement post IPO and (4) the perceived quality of the private equity firm. We then considered how these independent variables impacted two dependent variables, the attractiveness of the IPO and the expected degree of underpricing for the IPO.

Intensity of involvement refers to the density of activities or resource inputs by the private equity firm. In practice, this will predominantly be determined by time commitments in the monitoring, governance and mentoring of the company. It will be reflected in factors such as the number of board members from, or appointed by, the private equity firm, the frequency of financial reporting and the frequency and nature of contact, for example telephone calls versus on-site visits. Higher intensity of involvement represents a larger time and energy commitment to the investee company and, therefore, a higher resource commitment.

Despite Macmillan et al. (1988) early investigations suggesting that venture capitalists' level of intervention did not significantly impact performance, later findings of significant positive impacts now greatly outweigh MacMillan et al's conclusions (e.g., Cumming \& Johan, 2007; Gabrielsson \& Huse, 2002; Hellmann \& Puri, 2002; Sapienza, 1992; Sapienza, Manigart, \& Vermier, 1996). Sapienza (1992) found that the most effective venture capitalists were those that maintain frequent and open communications with investee companies, Sapienza and Gupta (1994) that more frequent interactions ensued when the proportion of venture capitalists on the investee company board was higher and Sapienza, Manigart and Vermier (1996) that increased governance was associated with greater added value. Syndication, that is multiple venture capital firms being involved with the same investee company, has been shown to be positively related to venture performance and survival rates (Brander, Amit, \& Antweiler, 2002; Hochberg, Ljungqvist, \& Lu, 2007). Kanniainen and Keuschnigg (2003) demonstrated that the optimum portfolio size is governed by the level of agency risk in investee companies, that is that time constraints on the venture capitalist are a key determinant of effective governance and mentoring and therefore performance. Further, van Osnabrugge and Robinson (2001) suggested that low numbers of portfolio companies per executive acts as a valued signal of superior selection, monitoring and mentoring to the market. The importance of portfolio size, and therefore, the level of time resource private equity managers can allocate to investee companies, has also been demonstrated by Jääskeläinen, Maula and Seppä (2006), Cumming (2006), Bernile, Cumming and Lyandres (2007), Cumming and Dai (2008), Cumming and Walz (2009) and Meulemen, Amess, Wright and Scholes (2009). Further, the significance of intensity of involvement has been evidenced by Bottazzi, Da Rin and Hellman (2008), who identified a positive relationship between venture capitalist intensity of involvement and their proportion of successful exits (defined as IPO and trade sales). This supported earlier findings by Cumming and Johan (2007) who also evidenced that involvement was positively associated with the 
number of board seats held by the venture capital firm and its degree of ownership.

Contributors to private equity firms' intensity of involvement will be: (1) their general disposition to involvement (MacMillan et al., 1988; Sweeting \& Wong, 1997), (2) the level of their investment (Cumming \& Johan, 2007a; Kaplan \& Strömberg, 2004) and (3) the level of previous business experience of individual venture capital partners (Bottazzi et al., 2008). With the levels of investment and board membership highly visible to financial analysts, it is hypothesised they will influence perceptions of intensity of involvement. These arguments, when considered together, suggest that the intensity of involvement will be a significant factor underpinning any certification role at IPO.

Duration of involvement refers to the length of time the private equity firm has had influence into the decision making processes of the investee company through a formal relationship. The longer a private equity firm has been involved with an investee company, the more opportunities it will have faced to influence decisions that could lead to presenting a more attractive proposition to the IPO market (Barry et al., 1990; Dolvin \& Pyles, 2006; Lerner, 1994; Sandström \& Westerholm, 2003; Timmons \& Bygrave, 1986; Wang, Wang, \& Lu, 2002). The relationship would likely have involved significant monitoring and information exchange (Gompers, 1995; Sahlman, 1990) and the longer the relationship the more monitoring and resource exchange will have taken place. Potential added value actions over the lifetime of the relationship include strategic and operational planning, management replacement and acting as a consultative sounding board (MacMillan et al., 1988; Sahlman, 1990; Sapienza \& Timmons, 1989). Rosenstein et al. (1993) and Sapienza and Amason (1993) have posited that most value is added at the early investment stages. Longer durations of involvement will more likely be associated with involvement at early stages and will therefore have resulted in private equity firms having more opportunities to add value at critical times over the lifetime of the venture. Indeed, Carter and Van Auken (1994) found venture capitalists who prefer to invest in earlier stages of development displayed a higher propensity to exercise control. Similarly, Flynn (2001) found that venture capitalists who were more active in earlier stages and those that had been involved since the venture's early stages had a greater impact on performance. The significance of relationship duration has been evidenced by Barry et al. (1990), who identified an association between reduced underpricing at IPO and the length of time the principal venture capitalist had spent on the board of the investee company, and Cumming and Johan (2010), who found greater added value for longer relationships among Canadian investee companies. These arguments, when considered together, suggest that the historic duration of involvement will be a significant factor underpinning any certification role at IPO.

The level of ownership retained at IPO is commonly cited as a signal of firm quality acting to reduce informational asymmetries through an ongoing commitment to the firm (see Brau \& Fawcett, 2006; Downes \& Heinkel, 1982; Gale \& Stiglitz, 1989; Grinblatt \& Hwang, 1989; Leland \& Pyle, 1977). Continued involvement by a substantial shareholder also provides continuity and can signal a mitigation of agency risk to new shareholders (Stoughton \& Zechner, 1998).

Private equity firms rarely sell all of their holdings at IPO (Barry et al., 1990; Brau \& Fawcett, 2006; Brav \& Gompers, 1997; Cao \& Lerner, 2009; DeGeorge \& Zeckhauser, 1993; Holthausen \& Larcker, 1996; Mian \& Rosenfeld, 1993; Morsfield \& Tan, 2006) and their continued involvement has been posited as contributing to the credibility of an offer (Barry et al., 1990; Brau \& Fawcett, 2006; Megginson \& Weiss, 1991). The degree of ownership has also been found to be associated with the level of value adding services provided by venture capitalists (Kaplan \& Strömberg, 2004). This infers higher ongoing ownership levels post IPO will be associated with higher involvement post IPO.

Brav and Gompers (1997), Stein and Bygrave (1990), Lange et al. (2001), Jain (2001), Jain and Kini (1995), Tykvovã and Walz (2007), Rindermann (2003), Bergström et al. (2006), Campbell and Frye (2006; 2009) and Krishnan et al (2009) have all evidenced a direct association between ongoing venture capitalist involvement and superior post IPO long run performance. Further, the proprietorship ratio, agency issues and a stable ownership structure have been shown to be a material influence on analysts' assessments of IPOs (Brennan \& Franks, 1997; Field \& Sheehan, 2004; Kim, Krinsky, \& Lee, 1995; Mear \& Firth, 1988; Roosenboom \& Van Der Goot, 2005). Thus, the degree of retained ownership, representing ongoing commitment, is likely to be a significant factor underpinning any certification role at IPO.

Private equity firm quality refers to the quality of the firm as perceived by the market which will be based on its reputation in the market. That is, the perceived quality of the firm will be grounded in the level of its reputational capital.

The characteristics of private equity firms that can contribute to perceptions of quality include size, age, extent of networks, structure (e.g., independent/corporate) and market share. Many of these characteristics have been 
investigated in terms of their impact on investee company performance as proxies of quality (e.g., Barry et al., 1990; Dolvin \& Pyles, 2006; Engel, 2004; Gompers \& Lerner, 1998, 2000; Hochberg et al., 2007; Lange et al., 2001; Lerner, 1994; Maula, Autio, \& Murray, 2005; Rosenstein et al., 1993). In addition, firm reputations will be influenced by perceived expertise in specific industrial sectors, track records in respect of their own performance and that of their previous IPOs and the reputations of individuals within the firm.

Rosenstein et al. (1993) found that venture capitalists on boards of investee companies were seen as adding no more value than other external directors unless they were from a "top 20" venture capital firm, whereupon their contribution was significantly superior. Similarly, Barry et al. (1990) found reduced underpricing at IPO only where "quality" venture capitalists and underwriters were involved. Dolvin (2005) and Dolvin and Pyles (2006) evidenced that higher quality venture capital firms perform a certification role, materialising through lower issuance costs and Lange et al. (2001) and Stein and Bygrave (1990) that higher quality venture capitalists are associated with higher returns. Similarly, both Campbell and Frye (2009) and Krishnan et al. (2009) found higher quality venture capitalists to be more involved in investee company monitoring post IPO, delivering superior performance. Therefore, the perceived quality of a private equity firm is likely to be a significant factor underpinning any certification role at IPO.

The research model posits a dependent variable of added value as perceived by the market, synonymous with the certification benefit. The perceived added value of private equity firm involvement is founded in historic and anticipated future resource exchange and reductions in informational asymmetry and agency risk. Dependent variables for the study were selected to encapsulate different ways in which perceived added value may manifest into constructs that can be readily understood and informatively assessed by the research subjects. The constructs adopted were those of the general attractiveness of the IPO and expectations on the level of (raw) underpricing.

Assessing and valuing public companies is one of the key roles of financial analysts (Biggs, 1984; Bing, 1971). Venture capitalist involvement is posited as impacting positively on valuations and, therefore, market attractiveness (Jain \& Kini, 1995), although there is some disagreement over the extent to which any added value is recognised by the market (Campbell \& Frye, 2006; Cohen \& Langberg, 2006). Nevertheless, if analysts perceive any added value from private equity firm involvement it will be reflected in their valuation of, and attraction to, a private equity backed IPO. Analysts' IPO valuations entail a highly complex process with numerous objective and subjective input variables. To simplify the cognitive process and facilitate the use of a simple, interval response scale, the first dependent variable was set as the general attractiveness of the IPO proposition (Note 1). The general attractiveness of the IPO under manipulated treatments, ceteris paribus, is therefore an informative dependent variable for determining the relative weights of the hypothesised determinants of certification.

Underpricing is a widely understood construct and a reduction in underpricing is commonly cited as a manifestation of a certification effect (e.g., Barry et al., 1990; Megginson \& Weiss, 1991). Accordingly, analysts' expectations of underpricing under manipulated treatments, ceteris paribus, should be an informative dependent variable for determining the relative weights of the hypothesised determinants of certification if underpricing is an appropriate proxy for certification.

The study examined, through an experimental technique, the relative weights of the hypothesised independent variables and their interactions in underpinning private equity firm certification. These are set out as research questions as follows:

The first question relates to the impact of private equity firm involvement on the attractiveness of the IPO.

Q1: What are the relative main and interactive weights of:

- Intensity of private equity firm involvement;

- Duration of private equity firm involvement;

- Commitment to ongoing private equity firm involvement;

- $\quad$ Perceived quality of the private equity firm in underpinning the attractiveness of a private equity backed IPO?

The second question relates to the expected impact of private equity firm involvement on the degree of underpricing at IPO.

Q2: What are the relative main and interactive weights of:

- Intensity of private equity firm involvement; 
- Duration of private equity firm involvement;

- Commitment to ongoing private equity firm involvement; and

- $\quad$ Perceived quality of the private equity firm in influencing expectations of underpricing of a private equity backed IPO?

\section{Methodology}

The research builds on existing theoretical perspectives using a mixed methodology. The use of a mixed methodology is common in business research (Collis \& Hussey, 2003) and the combining of qualitative and quantitative techniques delivers considerable complementarities including triangulation, completeness, credibility, enhanced explanatory power and context (Bryman, 2006a, 2006b; Greene, Caracelli, \& Graham, 1989; Patton, 1990; Yin, 2003). This research programme combined the quantitative technique of applying experimental treatments with the qualitative technique of semi-structured interviews.

The causal relationship hypothesised in the model was tested through a deductive process using an experimental technique adapted from the early works of Slovic and others (Slovic, 1969; Slovic, Fleissner, \& Bauman, 1972). This experimental approach delivers the key benefit of evidencing causality rather than simply a correlational association (Coolican, 2004; Keppel, 1982). Concurrently, interviews were conducted with financial analysts to deliver rich, contextual data on the research questions (Bryman, 1988; Creswell, 1998; Patton, 1990). Data from both elements of the study were integrated at the interpretation phase which enhances the confidence attributable to inferences of causality and the reliability of conclusions (Bryman, 1992; Creswell, 2003; Shadish, Cook, \& Campbell, 2002).

The quantitative element of the study adopted a systematic experimental design to present judgement tasks (for reviews see Libby, 1981; Slovic, Fischoff, \& Lichtenstein, 1977) in the form of combinations of different levels of the four independent variables. "The most important feature of the experimental method is that it is possible to infer a cause-effect relationship" (Keppel, 1982, p. 2 emphasis in original) (see also Coolican, 2004; Holland, 1986; Libby, 1981).

The method has been successfully applied in numerous studies of business decision making such as auditing (e.g., Ashton, 1974; Brown \& Solomon, 1990, 1991; Hooper \& Trotman, 1996), capital investments (e.g., Wood \& Ross, 2006), marketing decision making (e.g., Forlani, 2002) and managerial appointments (e.g., Hitt \& Barr, 1989) as well as extensively in studying judgement processes in financial analysis (e.g., Mear \& Firth, 1987, 1990; Milne \& Chan, 1999; Slovic, 1969; Slovic, Fleissner, \& Bauman, 1972; Wright, 1977). Use of the technique is now widely accepted (Keppel, 1982; Trotman, 1996). The within subjects (also known as repeated measures) design employed in this study is commonly used in the decision making literature (Libby, Artman, \& Willingham, 1985), is the most commonly used design for the study of learning transfer and practice effects (Keppel, 1982) and is considered effective in analysing problems related to cue usage (Trotman, 1996).

A fully crossed, within subjects design allows for the control of confounding variables as they can be absorbed into the instrument's design (Coolican, 2004; Trotman, 1996). This is because, for each respondent, any confounding variables remain constant across treatments, i.e., subjects act as their own control (Cox \& Reid, 2000; Keppel, 1982; Ryan, 2007; Trotman, 1996; Winer, Brown, \& Michels, 1991). Consequently, the design delivers high degrees of power, that is the ability to detect differences between treatment conditions when they exist and at very economical response levels (Coolican, 1994; Keppel, 1982).

The experiment was conducted by presenting to subjects all possible combinations arising from a fully crossed, two level, within subjects design testing the influence of four variables, i.e., presenting 16 scenarios (treatments) for assessment. Risks of practice and carryover effects and sensitisation (Keppel, 1982; Rubin, 1974; Slovic, Fischoff, \& Lichtenstein, 1977; Trotman, 1996; Winer, Brown, \& Michels, 1991) were mitigated by randomising the presentation of the 16 scenarios. Consequently, even if individual practice and carryover effects eventuated, they would not systematically bias results (Keppel, 1982; Trotman, 1996).

The need to develop a richer understanding of the judgemental decision making process requires the adoption of qualitative research techniques. This element of the study collected data through semi-structured interviews to deliver depth of understanding of the motives and actions of individuals who have daily involvement in the assessment and valuation process from their own perspective (Creswell, 1998, 2003; Patton, 1990). A semi-structured approach was adopted to facilitate the uncovering of a richness of data that survey methods and structured interviews do not reveal (Collis \& Hussey, 2003; Coolican, 2004; Flick, 2002; Fontana \& Frey, 2000). Semi-structured interviews allow the researcher to convey concern for the perspectives of subjects, allow subjects to express emphasis in areas they perceive as most significant and facilitate probing around meanings 
and explanations of comments, thereby delivering comprehensive data (Bryman, 1988; Patton, 1990). The use of semi-structured interviews is appropriate for theory informed research, when it is necessary to understand the construct of the situation from the perspective of the subject, when the sequential and causal nature of cues needs to be elucidated and when the respondent needs confidence in the confidentiality of discussions (Collis \& Hussey, 2003; Easterby-Smith, Thorpe, \& Lowe, 2002; Flick, 2002).

Combining experimental and qualitative methods contributes to the internal and external validity of the study. Internal validity refers to the validity of inferences of whether the observed impact on the dependent variable was actually caused by variations in the independent variable, rather than some other influence (Shadish, Cook, \& Campbell, 2002; Trotman, 1996). Within subject experimental treatments have strong internal validity (Collis \& Hussey, 2003; Coolican, 2004; Shadish et al., 2002). Analysis of the interview data contributed to considerations of other possible causes and the plausibility of those causes, thereby contributing further to internal validity (Bryman, 1988; Shadish et al., 2002; Trotman, 1996; Yin, 2003). External validity refers to the degree to which conclusions over a cause and effect relationship can be extrapolated to other actors or situations (Coolican, 2004; Shadish, Cook, \& Campbell, 2002). The experimental method generally has weak external validity because of the restrictive controls imposed to evidence the cause-effect relationship (Hofstedt \& Hughes, 1977; Shadish et al., 2002). The data obtained from qualitative methods often include more representative samples of constructs than experiments and broader sampling thereby enhancing external validity (Shadish et al., 2002). Under the combined design used in this study, the qualitative research contributes to improving this external validity by illustrating the broader applicability of identified relationships (Yin, 2003). The combined use of the two methods contributes further to external validity through the experiment providing statistical generalisability and the interviews analytical generalisability (Shadish et al., 2002; Yin, 2003). Thus, under a combined approach, the experiment delivers internal validity and the qualitative research construct and external validity.

The units of analysis for the study were individual financial analysts. This unit was selected as financial analysts can be considered expert in assessing a firm's value and perform this function as the main role of their daily work (Biggs, 1984). Analysts will be familiar with the assessment of both private equity backed and non-private equity backed companies. Further, they are used to making decisions based on qualitative information (Bouwman, Frishkoff, \& Frishkoff, 1987) and, because of their focus on listed companies, their views will not be encumbered by consideration of potential added value under other exit routes, that is their views will be directly relevant to the focus of this study, certification at IPO, without extraneous noise from other possible exit routes. Therefore, they make excellent subjects for experimental treatments on private equity firm certification at IPO. Analysts' views and reports are valued in the marketplace and, through these, they are a material influence in the determination of closing market prices on the day of an IPO's issue (Bouwman, Frishkoff, \& Frishkoff, 1987; O'Brien \& Bhushan, 1990; Schipper, 1991). Indeed, Schipper (1991) suggested studies of the perceptions and behaviours of analysts can deliver valuable insight into investor behaviour as a whole (see also Trueman, 1994; Welch, 2000). As recommended by Maines (1995), experienced analysts were selected to increase the validity of findings.

Data for the experimental treatments were collected through a personally addressed, self administered survey instrument issued by mail to financial analysts covering Australian equity markets. Mail surveys are posited as presenting few special sampling error problems (Dillman, 1991). The instrument was printed on two sides of A3 paper, folded to provide a four page, A4 sized booklet to allow ample space for a well set out and easy flow of questions (Dillman, 2000; Scott, 1961). The front cover of the booklet carried introductory information highlighting the salience of the subject to respondents (Heberlein \& Baumgartner, 1978; Scott, 1961) and instructions. The internal pages carried the experimental scenarios. The back cover collected self reported weights (not reported in this paper) as well as basic demographic data on the respondent. There were four variants of the survey instrument, the only difference in the variants being the order of presentation of scenarios to mitigate practice and carry over effects (Keppel, 1982; Trotman, 1996). The case order for each of the four variants was assigned randomly.

A total of eight interviews with buy-side financial analysts were conducted. Brief profiles of subjects are provided as Appendix I. Five interviewees were based in Sydney and three in Melbourne. All interviews were face-to-face, conducted at the workplaces of interviewees and followed an interview protocol for consistency. Interviews were audio recorded to ensure accurate and unbiased data recording and enhance dialogue flow through improved interviewer attentiveness (Collis \& Hussey, 2003; Coolican, 2004; Creswell, 1998; Easterby-Smith et al., 2002; Patton, 1990). Both the survey instrument and protocol were pretested. 


\section{Findings}

\subsection{Experiment Findings}

A total of 30 completed, usable instruments were returned. 30 completed responses sits at the top end of Coolican's (1994) recommended optimum range (25-30) for studies of homogeneous respondents for repeated measures designs and is ordinarily sufficient to deliver both low Type I and Type II errors.

The analysts cover a wide range of industrial sectors and experience levels, although as a group can be considered experienced with the mean experience level being 12.9 years and the median 11 years. Returns were dominated by buy-side analysts whose experience is mainly with larger IPOs brought to market by private equity companies rather than venture capital firms (Note 2). These results are unsurprising given the natures of the sample selection and local market. The sample was collected from publicly accessible internet sites resulting in the heavy bias in favour of buy-side analysts. Buy-side analysts more directly represent the market than sell-side analysts and so any bias in this direction does not detract from the validity of findings. The size of the Australian IPO market and relative immaturity of the private equity sector (EIU, 2008; Fleming, 2004; Strömberg, 2007) means that most analysts with experience of IPOs will have developed this experience considering offerings emerging from expansion and buyout backgrounds rather than directly from seed and early stage backgrounds, which are commonly associated with smaller technology or biotechnology companies, with an appeal only to specialist fund managers.

In an attempt to generate data on how extensively the independent variables captured the range of significant decision making variables, respondents were asked to score on a Likert scale of 1 (low) to 7 (high) how confident they felt that the variables "encompass the range of $\mathrm{VC} / \mathrm{PE}$ related characteristics you would consider in assessing an IPO with a VC/PE shareholding". 21 of the 30 respondents $(70 \%)$ noted their confidence level at the mid point of the scale or higher with a mean of 4.4, median of 5 and mode of 5 . This level of confidence indicates the model to be at least moderately strong in capturing the influential factors of private equity firm involvement as perceived by the market. In addition, the finding of large magnitude, statistically significant results with "gold standard" levels of power (Cohen, 1988; Coolican, 2004) for the determinants of attractiveness add further weight to the validity of the model as a robust one for the study of certification effects. Finally, residual plots and Ryan-Joiner (1976) tests suggested the data satisfied the assumption of normality and use of Mauchly's test statistic confirmed the data satisfied the necessary assumption of sphericity (Field, 2005).

An initial MANOVA test proved significant and so the dependent variables were subsequently analysed using individual ANOVA analysis (Coolican, 2004; Field, 2005).

The relative weights of $\mathrm{VC} / \mathrm{PE}$ related factors in contributing to the attractiveness of an IPO are presented in Table 1.

Table 1. Factor weightings for IPO attractiveness

\begin{tabular}{|c|c|c|c|c|c|c|}
\hline & & Intensity of Involvement & Duration of Involvement & Retained Ownership & Quality & \\
\hline \multicolumn{7}{|c|}{ Magnitude of Effect $\dagger$} \\
\hline \multirow{2}{*}{ Rating } & High & 3.296 & 3.492 & 3.75 & 3.929 & \\
\hline & Low & 3.404 & 3.208 & 2.95 & 2.771 & \\
\hline \multicolumn{2}{|c|}{ Difference } & -0.108 & $0.284 *$ & $0.8^{*}$ & $1.158^{*}$ & \\
\hline \multicolumn{2}{|c|}{$\%$ of summed absolute differences } & $4.60 \%$ & $12.09 \%$ & $34.04 \%$ & $49.28 \%$ & $100 \%$ \\
\hline \multicolumn{7}{|l|}{$\mathrm{n}=30$} \\
\hline \multicolumn{2}{|l|}{ Rank } & 4 & 3 & 2 & 1 & \\
\hline \multicolumn{7}{|c|}{ Effect Size $\vdots$} \\
\hline \multicolumn{2}{|c|}{ Main Effects } & $0.90 \%$ & $8.53 \%$ & $20.81 \%$ & $37.43 \%$ & $67.68 \%$ \\
\hline \multicolumn{2}{|c|}{ Interactions $\$+$} & $1.29 \%$ & $13.29 \%$ & $8.01 \%$ & $9.73 \%$ & $32.32 \%$ \\
\hline \multicolumn{2}{|c|}{ Combined Effects } & $2.20 \%$ & $21.82 \%$ & $28.83 \%$ & $47.15 \%$ & $100 \%$ \\
\hline \multicolumn{7}{|l|}{$\mathrm{n}=30$} \\
\hline \multicolumn{2}{|l|}{ Rank } & 4 & 3 & 2 & 1 & \\
\hline
\end{tabular}

Note. $*$ Significant at alpha $=0.05$; $\uparrow$ The difference in judgement means across treatments (Slovic, 1969); $¥$ Effect size is measured by partial eta squared; $\$$ Interaction effects are assigned to factors weighted by the size of main effect for that factor. 
Both the Magnitude of Effect and the Effect Size measures show consistent rank orders and suggest that private equity firm quality dominates other factors. Further, intensity of involvement appears to make a negligible contribution to certification, potentially even having a negative certification effect, although this influence is very small and not statistically significant. The Magnitude of Effect analysis (difference in means between treatments) (Slovic, 1969) shows a significant difference in means for all but the intensity of involvement factor.

The detailed Effect Size analysis (Table 2) shows large and statistically significant (at the $5 \%$ level) main effects for the retained ownership and quality factors. The statistical power of both variables is also high, suggesting there is little likelihood of Type II error (Cohen, 1988; Coolican, 2004). The duration factor also shows significance at the $5 \%$ level, however, just fails to attain a magnitude sufficient to be classified as large and is classified as moderate (Coolican, 2004). It also shows a reasonably strong power level. As with the Magnitude of Effects analysis, the intensity of involvement factor fails to satisfy standard statistical tests of significance. The interaction between intensity and duration is also statistically significant, is large in its magnitude and has a reasonably strong power level. The finding of moderate or large, statistically significant main effect sizes for three of the four variables plus a large, significant interaction under these controlled conditions further confirms the validity of the model and the existence of a causal relationship between the posited variables and IPO attractiveness.

Table 2. Effect sizes for IPO attractiveness

\begin{tabular}{llll}
\hline Factor & Effect Size + & $\mathrm{p}$ value & Power \\
\hline Main Effects & & & \\
Intensity & 0.01 & 0.531 & 0.09 \\
Duration & 0.13 & $0.044^{*}$ & 0.53 \\
Retained Ownership & $0.32^{* *}$ & $0.001^{*}$ & $0.95^{* * *}$ \\
Quality & $0.58^{* *}$ & $0 *$ & $1.00^{* * *}$ \\
Total Main Effects & 1.05 & & \\
Interactions & & & 0.67 \\
Intensity*Duration & $0.17^{* *}$ & $0.019^{*}$ & \\
Sum of non significant interactions & 0.33 & & \\
Total Interactions & 0.50 & & \\
Sum of Effect Sizes & 1.55 & & \\
\hline
\end{tabular}

Note. * Significant at alpha $=0.05 ; * *$ An effect size of 0.14 or above can be considered large (Coolican, 2004); $\$$ Effect size is measured by partial eta squared; *** exceeds the 0.8 'gold' standard for power (J. Cohen, 1988; Coolican, 2004).

The statistically significant and large interaction effect between the intensity and duration of involvement variables is worthy of particular note because it reveals that the intensity of involvement, when considered interactively with duration, is a relevant factor and yet when considered in isolation is not. The nature of this relationship warrants further investigation.

The relative weights of private equity related factors in contributing to expectations of underpricing are reported in Table 3.

The two sets of measures are consistent in their ranked order of importance of factors and, as with attractiveness, show the quality of the private equity firm dominating other factors. For expectations of underpricing, the quality of the private equity firm is the only cue that registers a statistically significant difference in means between treatments (Magnitude of Effect) with higher quality private equity firms expected to deliver more highly underpriced IPOs. Likewise, this factor is the only one that demonstrates a large and statistically significant Effect Size (Table 4). There are no significant interactions. A further, notable, result of this analysis is its low sum of Effect Sizes. This poor explanatory power of the model, combined with a lack of statistical significance for the majority of factors, suggests these factors have a limited causal influence on expected underpricing. 
Table 3. Factor weightings for expected underpricing

\begin{tabular}{|c|c|c|c|c|c|c|}
\hline & & Intensity of Involvement & Duration of Involvement & Retained Ownership & Quality & \\
\hline \multicolumn{7}{|c|}{ Magnitude of Effect $\dagger$} \\
\hline \multirow{2}{*}{ Rating } & High & 3.456 & 3.527 & 3.675 & 3.796 & \\
\hline & Low & 3.558 & 3.488 & 3.34 & 3.219 & \\
\hline \multicolumn{2}{|c|}{ Difference } & -0.102 & 0.039 & 0.335 & $0.577 *$ & \\
\hline \multicolumn{2}{|c|}{$\%$ of summed absolute differences } & $9.69 \%$ & $3.70 \%$ & $31.81 \%$ & $54.80 \%$ & $100 \%$ \\
\hline \multicolumn{7}{|l|}{$n=30$} \\
\hline \multicolumn{2}{|l|}{ Rank } & 3 & 4 & 2 & 1 & \\
\hline \multicolumn{7}{|c|}{ Effect Size $\ddagger$} \\
\hline \multicolumn{2}{|c|}{ Main Effects } & $1.96 \%$ & $0.71 \%$ & $13.19 \%$ & $24.06 \%$ & $39.93 \%$ \\
\hline \multicolumn{2}{|c|}{ Interactions $t+$} & $7.10 \%$ & $2.65 \%$ & $26.13 \%$ & $24.19 \%$ & $60.07 \%$ \\
\hline \multicolumn{2}{|c|}{ Combined Effects } & $9.06 \%$ & $3.36 \%$ & $39.32 \%$ & $48.25 \%$ & $100.00 \%$ \\
\hline \multicolumn{7}{|l|}{$n=30$} \\
\hline \multicolumn{2}{|l|}{ Rank } & 3 & 4 & 2 & 1 & \\
\hline
\end{tabular}

Note. $*$ Significant at alpha $=0.05 ; \dagger$ The difference in judgement means across treatments (Slovic, 1969); $\$$ Effect size is measured by partial eta squared; $+\uparrow$ Interaction effects are assigned to factors weighted by the size of main effect for that factor.

Table 4. Effect sizes for expected underpricing

\begin{tabular}{llll}
\hline Factor & Effect Size + & $\mathrm{p}$ value & Power \\
\hline Main Effects & & & \\
Intensity & 0.01 & 0.572 & 0.09 \\
Duration & 0.00 & 0.752 & 0.06 \\
Retained Ownership & 0.07 & 0.14 & 0.31 \\
Quality & $0.14^{* *}$ & $0.042^{*}$ & 0.54 \\
Total Main Effects & 0.22 & & \\
Interactions & & & \\
Sum of non significant interactions & 0.34 & & \\
Total Interactions & 0.34 & & \\
Sum of Effect Sizes & 0.56 & & \\
\hline
\end{tabular}

Note. $*$ Significant at alpha $=0.05 ; * *$ An effect size of 0.14 or above can be considered large (Coolican, 2004); $\$$ Effect size is measured by partial eta squared.

\subsection{Interview Findings}

Private equity firms are considered to be influential over IPO pricing and are perceived to be associated with expectations of lower first day gains (underpricing). Subjects, however, suggested this was attributable to private equity firms being relatively sophisticated investors with the knowledge and skills to negotiate more aggressively with brokers and thereby obtain keener offer prices. This point is illustrated below with several quotes from subjects.

"Of course they want to reduce it [underpricing], they want to take it as far as they can. And will the PE be more sophisticated in avoiding that, absolutely."

\section{Subject A}

“They're probably more aggressive on price, yeah. ... They're probably more market savvy than just a business that's making ball bearings or something."

\section{Subject $\mathbf{F}$}

"You might expect PE, maybe play a bit harder ball and try and get a particular price, maybe that'll limit the upside on day one. I'd guess they might be a little bit more savvy in knowing what the prices will be."

\section{Subject G}

"They are probably pricing an IPO opportunity to near perfection." 


\section{Subject H}

"In the case of a non-PE [backed] company coming to market, in terms of the stock market it is highly likely that the vendor shareholders or the major shareholders and the founders are going to be far less sophisticated in stock market terms than the broker and so where you tend to get underpriced IPOs is from that sphere. PE floats tend to be slightly finer priced because you've got sophisticated folks on both sides of the table."

\section{Subject E}

"Lower [first day gain]. because they want the highest price they can possibly get and they want to screw as much out of the institutional buyers as they can."

\section{Subject C}

These remarks suggest reduced underpricing arises from reduced informational asymmetry between the vendor and the broker in setting the offer price and not reduced informational asymmetry between the vendor and the purchaser through a certification effect to the market.

\section{Discussion}

Underpricing plays a major role in the study of IPOs and certification where reduced underpricing is commonly used as a proxy for certification. It has been from the seminal studies of Megginson and Weiss (1991) and Barry et al. (1990) in the early 1990s, and remains so today. In various studies around the world private equity firm involvement has frequently been found to be associated with reduced underpricing. This has been the case in the US, the UK, France, the Netherlands and Japan (Barry et al., 1990; Bergström et al., 2006; Hamao et al., 2000; Megginson \& Weiss, 1991; Van Der Geest \& Van Frederikslust, 2001). However, it has also been shown to be associated with the perceived quality of the underwriter and auditor (Cao \& Lerner, 2009; Carter \& Manaster, 1990; Logue, 1973; Michaely \& Shaw, 1995; Titman \& Trueman, 1986), both of which have also been evidenced as associated with the quality of the private equity firm (Bradley \& Jordan, 2002; Dolvin \& Pyles, 2006; Francis et al., 2003; Lee \& Wahal, 2004; Megginson \& Weiss, 1991; Stein \& Bygrave, 1990). The degree of underpricing has also been found to be associated with market conditions, company and issue size, promotional activity, the level of retained ownership, the dispersion of shares post IPO, government interference and across different definitions of underpricing (Beatty \& Ritter, 1986; Beatty \& Welch, 1996; Benveniste \& Wilhelm, 1990; Brennan \& Franks, 1997; Gale \& Stiglitz, 1989; Grinblatt \& Hwang, 1989; Habib \& Ljungqvist, 2001; Hanley, 1993; Hunt-McCool et al., 1996; Leland \& Pyle, 1977; Loughran et al., 1994; Rajan \& Servaes, 1997; Ritter, 1987, 1991). With so many justifications proffered for underpricing and significant multicollinearity across them, it is difficult to evidence causality for any. Even in the US context of large data sets, in this noisy environment conclusions on the relationship between private equity firm involvement and reduced underpricing have been inconsistent over time (see Barry et al., 1990; Bradley \& Jordan, 2002; Brav \& Gompers, 2003; Dolvin \& Pyles, 2006; Francis et al., 2003; Lee \& Wahal, 2004; Megginson \& Weiss, 1991) and causal relationships not evidenced. This study has delivered additional information on this conundrum. A model that has been shown to be reasonably robust in explaining the determinants of certification was relatively poor in explaining expectations of underpricing. It has evidenced, under controlled conditions, an incongruence between the attractiveness of private equity backed IPOs and expectations of their underpricing. Arguably then, reduced underpricing is at best a noisy measure of private equity firm certification and at worst an inappropriate one, particularly so if data limitations preclude the control of key correlated variables such as underwriter quality, issue size, industry sector and promotional spend. The conclusion is that underpricing is too noisy a variable to be appropriately used as a proxy for certification in the Australian market. This is also likely to be the case for other markets with limited data. The application of the research methods used in this study to US subjects would be highly enlightening on the appropriateness of using underpricing as a proxy measure for certification in the US context where data limitations are less restrictive.

\section{Conclusions}

This research highlights the dangers of following too closely a body of work dominated by correlational studies using large data sets without due consideration of the context to which the method is being applied. With limited data sets it is often difficult to control for highly noisy variables, leading to the use of inappropriate proxy measures and misguided conclusions. The research model adopted in this research appears robust in explaining the determinants of private equity firm certification and yet poor at explaining the determinants of the expected level of underpricing. One of the key strengths of the experimental method is that where an effect exists, the method will pick it up. Consequently, it appears these factors are relevant influences on certification but not on expected underpricing. That is, there is an incongruence between private equity firm certification and underpricing. This is 
because the determinants of expected underpricing are more extensive and the noise created by other influences renders the model, as specified, a poor predictor. The conclusion is that reduced underpricing is an inappropriate proxy for assessing a certification effect by private equity firms to the market when other influences on underpricing cannot be controlled for.

Equally important is the correct specification of relationships. The use of underpricing as a proxy for a private equity firm certification effect is further undermined by consideration of where and how informational asymmetry is reduced during private equity backed IPOs. This research suggests that it is the broker that has the dominant influence over pricing and that while lower underpricing is expected for private equity backed IPOs, it is founded in reduced informational asymmetry between private equity firms and brokers, not private equity firms and the market. Reduced underpricing, therefore, is not a reflection of reduced informational asymmetry between private equity firms and the market and should not be used as a proxy for certification in the absence of adequate controls. A more robust proxy of private equity firm certification would reflect the relative weights of reputation, duration of involvement and retained ownership in its operation.

There are several limitations to the study and the application of its findings derived from the target subjects and their sphere of expertise and experience. Firstly, the research was confined to Australian based subjects applying their assessments and comments to Australian experience and market conditions. In particular, the experiences relayed were dominated by exposure to more mature investments, including later stage funding rounds, investments in more mature private companies and previously public companies that had been taken private, that is, experiences mostly excluded experience of early stage investments. Accordingly, the conclusion that underpricing is an inappropriate proxy for certification should only be extended to early stage (venture capital) focused firms following additional confirmatory research. Similarly, research with other subject groups, such as brokers, auditors and solicitors, will add greater understanding of the limitations of using underpricing as a proxy for certification. Finally, the market perspective in the study was represented by buy-side analysts. While this is commonplace and well accepted in academic research (Schipper, 1991; Trueman, 1994; Welch, 2000), it is conceivable that these institutional analysts may display certain biases compared to the market as a whole. For example, their training may render them less susceptible to market fads or to over optimism during hot issue periods. Countering this is that their remuneration structures could lead to pressures to be active during hot issue periods. On balance, and with institutional buyers comprising a large section of the market as a whole, their views can be considered representative of the market, however public perceptions may differ.

This research has introduced a new methodology to the area of understanding private equity backed IPO certification. It is important this direction is pursued in respect of testing the applicability of Australian findings to other markets, in researching the certification effects of other actors in the IPO process and in exploring the underlying dimensions of reputational capital in more depth.

Finally, it is essential that research is instigated to search for and refine a more robust proxy of certification for use in analysing IPOs. This proxy should better reflect the relative weights of reputation, duration of involvement and retained ownership in its operation as these have been shown to be causal determinants of private equity firm certification at IPO.

\section{References}

Akerlof, G. A. (1970). The market for "Lemons": Quality uncertainty and the market mechanism. Quarterly Journal of Economics, 84(3), 488-500. http://dx.doi.org/10.2307/1879431

Allen, F., \& Faulhaber, G. R. (1989). Signalling by underpricing in the IPO market. Journal of Financial Economics, 23(2), 303-323. http://dx.doi.org/10.1016/0304-405X(89)90060-3

Ashton, R. H. (1974). Cue utilization and expert judgments: A comparison of independent auditors with other judges. Journal of Applied Psychology, 59(4), 437-444. http://dx.doi.org/10.1037/h0037314

AVCAL. (2008). The private equity market in Australia-An overview. Sydney: The Australian Private Equity and Venture Capital Association.

Balboa, M., \& Marti, J. (2007). Factors that determine the reputation of private equity managers in developing markets. Journal of Business Venturing, 22(4), 453-480. http://dx.doi.org/10.1016/j.jbusvent.2006.05.004

Baron, D. P. (1982). A model of the demand for investment banking advising and distribution services for new issues. The Journal of Finance, 37(4), 955-976. http://dx.doi.org/10.1111/j.1540-6261.1982.tb03591.x

Barry, C. B., Muscarella, C. J., Peavy, I. I. I. J. W., \& Vetsuypens, M. R. (1990). The role of venture capital in the creation of public companies: Evidence from the going-public process. Journal of Financial Economics, 
$27(2), 447-471$.

Beatty, R. P., \& Ritter, J. R. (1986). Investment banking, reputation, and the underpricing of initial public $\begin{array}{llll}\text { offerings. Journal of } & \text { Financial }\end{array}$ http://dx.doi.org/10.1016/0304-405X(86)90055-3

Beatty, R. P., \& Welch, I. (1996). Issuer expenses and legal liability in initial public offerings. Journal of Law \& Economics, 39, 545-602.

Benveniste, L. M., \& Spindt, P. A. (1989). How investment bankers determine the offer price and allocation of new issues. Journal of Financial Economics, 24(2), 343-361. http://dx.doi.org/10.1016/0304-405X(89)90051

Benveniste, L. M., \& Wilhelm, W. J. (1990). A comparative analysis of IPO proceeds under alternative regulatory environments. Journal of Financial Economics, 28(1-2), 173-207. http://dx.doi.org/10.1016/0304-405X(90)90052-2

Bergström, C., Nilsson, D., \& Wahlberg, M. (2006). Underpricing and long-run performance patterns of European private-equity-backed and non-private-equity-backed IPOs. Journal of Private Equity, 9(4), 1647. http://dx.doi.org/10.3905/jpe.2006.650457

Bernile, G., Cumming, D. J., \& Lyandres, E. (2007). The size of venture capital and private equity fund portfolios. Journal of Corporate Finance, 13(4), 564-590.

Biggs, S. F. (1984). Financial analysts' information search in the assessment of corporate earning power. $\begin{array}{llll}\text { Accounting, } & \text { Organizations } & \text { Society, } & \text { 313-323 }\end{array}$ http://dx.doi.org/10.1016/0361-3682(84)90015-1

Bing, R. A. (1971). Survey of practitioners' stock evaluation methods. Financial Analysts Journal, 27(3), 55-60.

Booth, J. R., \& Smith, R. L. (1986). Capital raising, underwriting and the certification hypothesis. Journal of Financial Economics, 15(1-2), 261-281. http://dx.doi.org/10.1016/0304-405X(86)90057-7

Bottazzi, L., Da Rin, M., \& Hellmann, T. (2008). Who are the active investors? Evidence from venture capital. Journal of Financial Economics, 89(3), 488-512. http://dx.doi.org/10.1016/j.jfineco.2007.09.003

Bouwman, M. J., Frishkoff, P. A., \& Frishkoff, P. (1987). How do financial analysts make decisions? A process model of the investment screening decision. Accounting, Organizations and Society, 12(1), 1-29. http://dx.doi.org/10.1016/0361-3682(87)90013-4

Bradley, D. J., \& Jordan, B. D. (2002). Partial Adjustment to Public Information and IPO Underpricing. The Journal of Financial and Quantitative Analysis, 37(4), 595-616.

Brander, J. A., Amit, R., \& Antweiler, W. (2002). Venture-capital syndication: improved venture selection vs. the value-added hypothesis. Journal of Economics \& Management Strategy, 11(3), 422-451. http://dx.doi.org/10.1111/j.1430-9134.2002.00423.x

Brau, J. C., \& Fawcett, S. E. (2006). Initial public offerings: An analysis of theory and practice. The Journal of Finance, 61(1), 399-436. http://dx.doi.org/10.1111/j.1540-6261.2006.00840.x

Brav, A., \& Gompers, P. A. (1997). Myth or reality? The long-run underperformance of initial public offerings: Evidence from venture and nonventure capital-backed companies. Journal of Finance, 52(5), 1791-1821. http://dx.doi.org/10.1111/j.1540-6261.1997.tb02742.x

Brav, A., \& Gompers, P. A. (2003). The role of lockups in initial public offerings. The Review of Financial Studies, 16(1), 1-29. http://dx.doi.org/10.1093/rfs/16.1.1

Brennan, M. J., \& Franks, J. (1997). Underpricing, ownership and control in initial public offerings of equity securities in the UK. Journal of Financial Economics, 45(3), 391-413. $\mathrm{http} / / / \mathrm{dx}$.doi.org/10.1016/S0304-405X(97)00022-6

Brown, C. E., \& Solomon, I. (1990). Auditor configural information processing in control risk assessment. Auditing, 9(3), 17-38.

Brown, C. E., \& Solomon, I. (1991). Configural information processing in auditing: The role of domain-specific knowledge. The Accounting Review, 66(1), 100-119.

Bryman, A. (1988). Quantity and quality in social research. London: Unwin Hyman.

Bryman, A. (1992). Quantitative and qualitative research: Further reflections on their integration. In J. Brannen 
(Ed.), Mixing methods: Qualitative and quantitative research (pp. 57-78). Aldershot: Ashgate Publishing.

Bryman, A. (2006a). Integrating quantitative and qualitative research: How is it done? Qualitative Research, 6(1), 97-113. http://dx.doi.org/10.1177/1468794106058877

Bryman, A. (2006b). Mixed methods (Vol. 1). London: Sage Publications.

Campbell II, T. L., \& Frye, M. B. (2006). Venture capitalist involvement and the long-run performance of IPOs. Journal of Private Equity, 10(1), 7-17. http://dx.doi.org/10.3905/jpe.2006.667555

Campbell II, T. L., \& Frye, M. B. (2009). Venture capitalist monitoring: Evidence from governance structures. The Quarterly Review of Economics and Finance, 49(2), 265-282. http://dx.doi.org/10.2139/ssrn.1131305

Cao, J. X., \& Lerner, J. (2009). The performance of reverse leveraged buyouts. Journal of Financial Economics, 91(2), 139-157.

Carter, R. B., Dark, F. H., \& Singh, A. K. (1998). Underwriter reputation, initial returns, and the long-run performance of IPO stocks. Journal of Finance, 53(1), 285. http://dx.doi.org/10.1111/0022-1082.104624

Carter, R. B., \& Manaster, S. (1990). Initial public offerings and underwriter reputation. Journal of Finance, 45(4), 1045. http://dx.doi.org/10.1111/j.1540-6261.1990.tb02426.x

Carter, R. B., \& Van Auken, H. E. (1994). Venture capital firms' preferences for projects in particular stages of development. Journal of Small Business Management, 32(1), 60-73.

Cohen, D. A., \& Langberg, N. (2006). Venture capital financing and the informativeness of earnings. NYU Working Paper. SSRN, 1280719.

Cohen, J. (1988). Statistical power analysis for the behavioral sciences (2nd ed.). Hillsdale, NJ: Lawrence Erlbaum Associates.

Collis, J., \& Hussey, R. (2003). Business research (2nd ed.). Basingstoke: Palgrave MacMillan.

Coolican, H. (1994). Research methods and statistics in psychology (2nd ed.). London: Hodder \& Stoughton.

Coolican, H. (2004). Research methods and statistics in psychology (4th ed.). London: Hodder \& Stoughton.

Cox, D. R., \& Reid, N. (2000). The theory of the design of experiments. Boca Raton, Fl: Chapman \& Hall.

Creswell, J. W. (1998). Qualitative inquiry and research design: Choosing among five traditions. Thousand Oaks: Sage Publications.

Creswell, J. W. (2003). Research design: Qualitative, quantitative, and mixed method approaches (2nd ed.). ThousanD Oaks: Sage Publications.

Cumming, D. J. (2006). The determinants of venture capital portfolio size: Empirical evidence. Journal of Business, 79(3), 1083-1126.

Cumming, D. J., \& Dai, N. (2008). Limited attention: Fund size and valuation. Working paper, SSRN, 1099465. http://dx.doi.org/10.2139/ssrn.1099465

Cumming, D. J., \& Johan, S. (2007). Advice and monitoring in venture finance. Financial Markets and Portfolio Management, 21(1), 3-43. http://dx.doi.org/10.1007/s11408-006-0041-3

Cumming, D. J., \& Johan, S. (2010). Venture capital investment duration. Journal of Small Business Management, 48(2), 228-257. http://dx.doi.org/10.1111/j.1540-627X.2010.00293.x

Cumming, D. J., \& Walz, U. (2009). Private equity returns and disclosure around the world. SSRN, 1370726.

Da Silva Rosa, R., Velayuthen, G., \& Walter, T. S. (2003). The sharemarket performance of Australian venture capital-backed and non-venture capital-backed IPOs. Pacific-Basin Finance Journal, 11(2), 197.

DeGeorge, F., \& Zeckhauser, R. (1993). The reverse LBO decision and firm performance: Theory and evidence. Journal of Finance, 48(4), 1323-1348. http://dx.doi.org/10.1111/j.1540-6261.1993.tb04756.x

Dillman, D. A. (1991). The design and administration of mail surveys. Annual Review of Sociology, 17(1), 225 249. http://dx.doi.org/10.1146/annurev.so.17.080191.001301

Dillman, D. A. (2000). Mail and internet surveys: The Tailored design method (2nd ed.). New York: John Wiley \& Sons.

Dolvin, S. D. (2005). Venture capitalist certification of IPOs. Venture Capital, 7(2), 131-148. http://dx.doi.org/10.1080/1369106042000335601 
Dolvin, S. D., \& Pyles, M. K. (2006). Venture capitalist quality and IPO certification. Venture Capital, 8(4), 353371. http://dx.doi.org/10.1080/13691060600759782

Downes, D. H., \& Heinkel, R. (1982). Signaling and the valuation of unseasoned new issues. The Journal of Finance, 37(1), 1-10. http://dx.doi.org/10.1111/j.1540-6261.1982.tb01091.x

Easterby-Smith, M., Thorpe, R., \& Lowe, A. (2002). Management research: An introduction (2nd ed.). London: Sage Publications.

EIU. (2008). Private equity moves in: The impact on business in Australia. Economist Intelligence Unit.

Engel, D. (2004). The performance of venture-backed firms: The effect of venture capital company characteristics. Industry \& Innovation, 11(3), 249-263. http://dx.doi.org/10.1080/1366271042000265401

Field, A. (2005). Discovering Statistics Using SPSS (2nd ed.). London: Sage Publications.

Field, L. C., \& Sheehan, D. P. (2004). IPO underpricing and outside blockholdings. Journal of Corporate Finance, 10(2), 263-280. http://dx.doi.org/10.1016/S0929-1199(03)00057-9

Fleming, G. (2004). Venture capital returns in Australia. Venture Capital, 6(1), 23-45. http://dx.doi.org/10.1080/1369106042000175573

Flick, U. (2002). Semi-structured interviews: An introduction to qualitative research (pp. 74-95). London: Sage Publications.

Flynn, D. (2001). Life cycles of new venture organizations: Different factors affecting performance. Journal of Developmental Entrepreneurship, 6(1), 41.

Fontana, A., \& Frey, J. H. (2000). The interview: From structured questions to negotiated text. In N. K. Denzin \& Y. S. Lincoln (Eds.), Handbook of qualitative research (2nd ed., pp. 645-672). Thousand Oaks: Sage Publications.

Forlani, D. (2002). Risk and rationality: The influence of decision domain and perceived outcome on managers' high risk decisions. Journal of Behavioral Decision Making, 15(2), 125-140. http://dx.doi.org/10.1002/bdm.406

Francis, B. B., Hasan, I., \& Hu, C. (2003). Deliberate underpricing and price support: Venture backed and nonventure backed IPOs. In A. Ginsberg \& I. Hasan (Eds.), New venture investment: Choices and consequences (pp. 281-301). Amsterdam: Elsevier.

Franzke, S. (2003). Underpricing of venture-backed and non-venture backed IPOs: Germany's Neuer Markt. Working Paper, Centre for Financial Studies.

Gabrielsson, J., \& Huse, M. (2002). The venture capitalist and the board of directors in SMEs: Roles and processes. Venture Capital, 4(2), 125-146. http://dx.doi.org/10.1080/13691060110094397

Gale, I., \& Stiglitz, J. E. (1989). The informational content of initial public offerings. Journal of Finance, 44(2), 469-477. http://dx.doi.org/10.1111/j.1540-6261.1989.tb05066.x

Gompers, P. A. (1995). Optimal investment, monitoring, and the staging of venture capital. Journal of Finance, 50(5), 1461-1489. http://dx.doi.org/10.1111/j.1540-6261.1995.tb05185.x

Gompers, P. A. (1996). Grandstanding in the venture capital industry. Journal of Financial Economics, 42(1), 133-156. http://dx.doi.org/10.1016/0304-405X(96)00874-4

Gompers, P. A., \& Lerner, J. (1998). What drives venture capital fundraising? Brookings Papers on Economic Activity. Microeconomics, 1998, 149-204.

Gompers, P. A., \& Lerner, J. (2000). The determinants of corporate venture capital success: Organizational structure, incentives, and Complementarities. In R. K. Morck (Ed.), Concentrated Corporate Ownership (pp. 17-53). Chicago: The University of Chicago Press.

Greene, J. C., Caracelli, V. J., \& Graham, W. F. (1989). Toward a conceptual framework for mixed-method evaluation designs. Educational Evaluation and Policy Analysis, 11(3), 255-274. http://dx.doi.org/10.3102/01623737011003255

Grinblatt, M., \& Hwang, C. Y. (1989). Signalling and the pricing of new issues. The Journal of Finance, 44(2), 393-420. http://dx.doi.org/10.1111/j.1540-6261.1989.tb05063.x

Habib, M. A., \& Ljungqvist, A. P. (2001). Underpricing and entrepreneurial wealth losses in IPOs: Theory and evidence. The Review of Financial Studies, 14(2), 433-458. http://dx.doi.org/10.1093/rfs/14.2.433 
Hamao, Y., Packer, F., \& Ritter, J. R. (2000). Institutional affiliation and the role of venture capital: Evidence from initial public offerings in Japan. Pacific-Basin Finance Journal, 8(5), 529-558.

Hanley, K. W. (1993). The underpricing of initial public offerings and the partial adjustment phenomenon. Journal of Financial Economics, 34(2), 231-250.

Heberlein, T. A., \& Baumgartner, R. (1978). Factors affecting response rates to mailed questionnaires: A quantitative analysis of the published literature. American Sociological Review, 43(4), 447-462. http://dx.doi.org/10.2307/2094771

Hellmann, T., \& Puri, M. (2002). Venture capital and the professionalization of start-up firms: Empirical evidence. Journal of Finance, 57(1), 169-197. http://dx.doi.org/10.1111/1540-6261.00419

Hitt, M. A., \& Barr, S. V. (1989). Managerial selection decision models: Examination of configural cue processing. Journal of Applied Psychology, 74(1), 53-61. http://dx.doi.org/10.1037/0021-9010.74.1.53

Hochberg, Y. V., Ljungqvist, A. P., \& Lu, Y. (2007). Whom you know matters: Venture capital networks and investment performance. Journal of Finance, 62(1), 251-301. http://dx.doi.org/10.1111/j.1540-6261.2007.01207.x

Hofstedt, T. R., \& Hughes, G. D. (1977). An experimental study of the judgment element in disclosure decisions. The Accounting Review, 52(2), 379-395.

Holland, P. W. (1986). Statistics and causal inference. Journal of the American Statistical Association, 81(396), 945-960. http://dx.doi.org/10.1080/01621459.1986.10478354

Holthausen, R. W., \& Larcker, D. F. (1996). The financial performance of reverse leveraged buyouts. Journal of Financial Economics, 42(3), 293-332.

Hooper, C., \& Trotman, K. T. (1996). Configural information processing in auditing: Further evidence. Accounting \& Business Research, 26(2), 125-136. http://dx.doi.org/10.1080/00014788.1996.9729504

How, J. C. Y., Izan, H. Y., \& Monroe, G. S. (1995). Differential information and the underpricing of initial public offerings: Australian evidence. Accounting \& Finance, 35(1), 87-105. http://dx.doi.org/10.1111/j.1467-629X.1995.tb00278.x

Hunt-McCool, J., Koh, S. C., \& Francis, B. B. (1996). Testing for deliberate underpricing in the IPO premarket: A stochastic frontier approach. The Review of Financial Studies, 9(4), 1251-1269. http://dx.doi.org/10.1093/rfs/9.4.1251

Ibbotson, R. G. (1975). Price performance of common stock new issues. Journal of Financial Economics, 2(3), 235-272. http://dx.doi.org/10.1016/0304-405X(75)90015-X

Jääskeläinen, M., Maula, M., \& Seppä, T. (2006). Allocation of attention to portfolio companies and the performance of venture capital firms. Entrepreneurship: Theory \& Practice, 30(2), 185-206. http://dx.doi.org/10.1111/j.1540-6520.2006.00117.x

Jain, B. A. (2001). Predictors of performance of venture capitalist-backed organizations. Journal of Business Research, 52(3), 223-233. http://dx.doi.org/10.1016/S0148-2963(99)00112-5

Jain, B. A., \& Kini, O. (1995). Venture capitalist participation and the post-issue operating performance of IPO firms. Managerial and Decision Economics, 16(6), 593-606. http://dx.doi.org/10.1002/mde.4090160603

Jegadeesh, N., Weinstein, M., \& Welch, I. (1993). An empirical investigation of IPO returns and subsequent equity offerings. Journal of Financial Economics, 34(2), 153-175.

Jensen, M. C., \& Meckling, W. H. (1976). Theory of the firm: Managerial behavior, agency costs and ownership structure. Journal of Financial Economics, 3(4), 305-360.

Kanniainen, V., \& Keuschnigg, C. (2003). The optimal portfolio of start-up firms in venture capital finance. Journal of Corporate Finance, 9(5), 521-534.

Kaplan, S. N., \& Strömberg, P. (2004). Characteristics, contracts, and actions: Evidence from venture capitalist analyses. Journal of Finance, 59(5), 2177-2210. http://dx.doi.org/10.1111/j.1540-6261.2004.00696.x

Keppel, G. (1982). Design and Analysis: A Researcher's Handbook (2nd ed.). Englewood Cliffs, NJ: Prentice Hall.

Kim, J. B., Krinsky, I., \& Lee, J. (1995). The role of financial variables in the pricing of Korean initial public $\begin{array}{lllll}\text { offerings. } & \text { Pacific-Basin } & \text { Finance } & \text { 3(4), }\end{array}$ 
http://dx.doi.org/10.1016/0927-538X(95)00017-F

Kraus, T., \& Burghof, H. P. (2003). Post-IPO performance and the exit of venture capitalists. EFMA 2003 Helsinki Meetings. SSRN, 407846. http://dx.doi.org/10.2139/ssrn.407846

Krishnan, C. N. V., Masulis, R. W., Ivanov, V., \& Singh, A. K. (2009). IPOs and venture capital reputation. SSRN, 910982.

Lange, J. E., Bygrave, W. D., Nishimoto, S., Roedel, J., \& Stock, W. (2001). Smart money? The impact of having top venture capital investors and underwriters backing a venture. Venture Capital, 3(4), 309-326. http://dx.doi.org/10.1080/13691060110037129

Lee, P. J., Taylor, S. L., \& Walter, T. S. (1999). IPO underpricing explanations: Implications from investor application and allocation schedules. Journal of Financial \& Quantitative Analysis, 34(4), 425. http://dx.doi.org/10.2307/2676228

Lee, P. M., \& Wahal, S. (2004). Grandstanding, certification and the underpricing of venture capital backed IPOs. Journal of Financial Economics, 73(2), 375-407. http://dx.doi.org/10.1016/j.jfineco.2003.09.003

Leland, H. E., \& Pyle, D. H. (1977). Informational asymmetries, financial structure, and financial intermediation. The Journal of Finance, 32(2), 371-387. http://dx.doi.org/10.1111/j.1540-6261.1977.tb03277.x

Lerner, J. (1994). Venture capitalists and the decision to go public. Journal of Financial Economics, 35(3), $293-$ 316.

Libby, R. (1981). Accounting and human information processing: Theory and applications. Englewood Cliffs: Prentice Hall.

Libby, R., Artman, J. T., \& Willingham, J. J. (1985). Process susceptibility, control risk and audit planning. Accounting Review, 60(2), 212-230.

Logue, D. E. (1973). On the pricing of unseasoned equity issues: 1965-1969. The Journal of Financial and Quantitative Analysis, 8(1), 91-103. http://dx.doi.org/10.2307/2329751

Loughran, T., Ritter, J. R., \& Rydqvist, K. (1994). Initial public offerings: International insights. Pacific-Basin Finance Journal, 2(2-3), 165-199.

MacMillan, I. C., Kulow, D. M., \& Khoylian, R. (1988). Venture capitalists' involvement in their investments: Extent and performance. Journal of Business Venturing, 4(1), 27-47. http://dx.doi.org/10.1016/0883-9026(89)90032-3

Maines, L. A. (1995). Judgment and decision-making research in financial accounting: A review and analysis. In R. H. Ashton \& A. H. Ashton (Eds.), Judgment and decision making research in accounting and auditing. Cambridge: Cambridge University Press.

Maula, M., Autio, E., \& Murray, G. (2005). Corporate venture capitalists and independent venture capitalists: What do they know, who do they know and should entrepreneurs care? Venture Capital, 7(1), 3-21. http://dx.doi.org/10.1080/1369106042000316332

Mear, R. W. T., \& Firth, M. A. (1987). Cue usage and self-insight of financial analysts. The Accounting Review, 62(1), 176-182.

Mear, R. W. T., \& Firth, M. A. (1988). Risk perceptions of financial analysts and the use of market and accounting data. Accounting \& Business Research, 18(72), 335-340. http://dx.doi.org/10.1080/00014788.1988.9729380

Mear, R. W. T., \& Firth, M. A. (1990). A parsimonious description of individual differences in financial analyst judgement professional adaptation. Journal of Accounting, Auditing \& Finance, 5(4), 499-520.

Megginson, W. L., \& Weiss, K. A. (1991). Venture capitalist certification in initial offerings. Journal of Finance, 46(3), 879-903. http://dx.doi.org/10.1111/j.1540-6261.1991.tb03770.x

Meulemen, M., Amess, K., Wright, M., \& Scholes, L. (2009). Agency, strategic entrepreneurship and the performance pf private equity-backed buyouts. Entrepreneurship: Theory \& Practice, 33(1), 213-239. http://dx.doi.org/10.1111/j.1540-6520.2008.00287.x

Mian, S., \& Rosenfeld, J. (1993). Takeover activity and the long-run performance of reverse leveraged buyouts. FM: The Journal of the Financial Management Association, 22(4), 46-57. http://dx.doi.org/10.2307/3665576 
Michaely, R., \& Shaw, W. H. (1995). Does the Choice of Auditor Convey Quality in an Initial Public Offering? FM: The Journal of the Financial Management Association, 24(4), 15-30. http://dx.doi.org/10.2307/3665948

Milne, M. J., \& Chan, C. C. C. (1999). Narrative corporate social disclosures: How much of a difference do they make to investment decision-making? The British Accounting Review, 31(4), 439-457. http://dx.doi.org/10.1006/bare.1999.0108

Morsfield, S. G., \& Tan, C. E. L. (2006). Do Venture Capitalists Influence the Decision to Manage Earnings in Initial Public Offerings? Accounting Review, 81(5), 1119-1150. http://dx.doi.org/10.2308/accr.2006.81.5.1119

Muscarella, C. J., \& Vetsuypens, M. R. (1989). The underpricing of "second" initial public offerings. Journal of Financial Research, 12(3), 183-192.

Neus, W., \& Walz, U. (2005). Exit timing of venture capitalists in the course of an initial public offering. Journal of Finacial Intermediation, 14(2), 253-277. http://dx.doi.org/10.1016/j.jfi.2004.02.003

O'Brien, P. C., \& Bhushan, R. (1990). Analyst following and institutional ownership. Journal of Accounting Research, 28, 55-76.

Patton, M. Q. (1990). Qualitative evaluation and research methods (2nd ed.). Newbury Park: Sage Publications.

Pfeffer, J., \& Salancik, G. R. (1978). The external control of organizations: A resource dependence perspective (2nd ed.). Stanford, California: Stanford University Press.

Rajan, R., \& Servaes, H. (1997). Analyst following of initial public offerings. Journal of Finance, 52(2), 507529. http://dx.doi.org/10.1111/j.1540-6261.1997.tb04811.x

Rindermann, G. (2003). Venture capitalist participation and the performance of IPO firms: Empirical evidence from France, Germany and the UK. EFMA 2003 Helsinki Meetings. SSRN, 425080. http://dx.doi.org/10.2139/ssrn.425080

Ritter, J. R. (1987). The costs of going public. Journal of Financial Economics, 19(2), 269-281.

Ritter, J. R. (1991). The long-run performance of initial public offerings. Journal of Finance, 46(1), 3-27. http://dx.doi.org/10.1111/j.1540-6261.1991.tb03743.x

Rock, K. (1986). Why new issues are underpriced. Journal of Financial Economics, 15(1-2), 187-212. http://dx.doi.org/10.1016/0304-405x(86)90054-1

Roosenboom, P., \& Van Der Goot, T. (2005). The effect of ownership and control on market valuation: Evidence from initial public offerings in The Netherlands. International Review of Financial Analysis, 14(1), 43-59. http://dx.doi.org/10.1016/j.irfa.2004.06.003

Rosenstein, J., Bruno, A. V., Bygrave, W. D., \& Taylor, N. T. (1993). The CEO, venture capitalists, and the board. Journal of Business Venturing, 8(2), 99. http://dx.doi.org/10.1016/0883-9026(93)90014-V

Rubin, D. B. (1974). Estimating causal effects of treatments in randomized and nonrandomized studies. Journal of Educational Psychology, 66(5), 688-701.

Ryan, T. A., \& Joiner, B. L. (1976). Normal probability plots and tests for normality. MINITAB 14, Information note.

Ryan, T. P. (2007). Modern experimental design. Hoboken, New Jersey: John Wiley \& Sons.

Sahlman, W. A. (1990). The structure and governance of venture-capital organizations. Journal of Financial Economics, 27(2), 473-521. http://dx.doi.org/10.1037/h0037350

Sandström, A., \& Westerholm, J. (2003). Post-issue performance of hot IPOs. In A. Ginsberg \& I. Hasan (Eds.), New venture investment: Choices and consequences (pp. 227-255). Amsterdam: Elsevier.

Sapienza, H. J. (1992). When do venture capitalists add value? Journal of Business Venturing, 7(1), 9-27.

Sapienza, H. J., \& Amason, A. C. (1993). Effects of innovativeness and venture stage on venture capitalist-entrepreneur relations. Interfaces, 23(6), 38-51.

Sapienza, H. J., \& Gupta, A. K. (1994). Impact of agency risks and task uncertainty on venture capitalist-CEO interaction. Academy of Management Journal, 37(6), 1618. http://dx.doi.org/10.2307/256802

Sapienza, H. J., Manigart, S., \& Vermier, W. (1996). Venture capitalist governance and value added in four $\begin{array}{lllll}\text { countries. Journal of } & \text { Business } & \text { Venturing, } & \text { 11(6), }\end{array}$ 
http://dx.doi.org/10.1016/S0883-9026(96)00052-3

Sapienza, H. J., \& Timmons, J. A. (1989). The roles of venture capitalists in new ventures: What determines their importance? Academy of Management Proceedings, 74-78.

Schipper, K. (1991). Analysts' Forecasts. Accounting Horizons, 105-121.

Scott, C. (1961). Research on mail surveys. Journal of the Royal Statistical Society. Series A (General), 124(2), 143-205.

Shadish, W. R., Cook, T. D., \& Campbell, D. T. (2002). Experimental and quasi-experimental designs for generalized causal inference. Boston: Houghton Mifflin.

Slovic, P. (1969). Analyzing the expert judge: A descriptive study of a stockbroker's decision process. Journal of Applied Psychology, 53(4), 255-263. http://dx.doi.org/10.1037/h0027773

Slovic, P., Fischoff, B., \& Lichtenstein, S. (1977). Behavioral decision theory. Annual Review of Pschology, 28, 1-39. http://dx.doi.org/10.1146/annurev.ps.28.020177.000245

Slovic, P., Fleissner, D., \& Bauman, W. S. (1972). Analyzing the use of information in investment decision making: A methodological proposal. The Journal of Business, 45(2), 283-301. http://dx.doi.org/10.1086/295448

Spiess, K. D., \& Pettway, R. H. (1997). The IPO and first seasoned equity sale: Issue proceeds, owner/managers' wealth, and the underpricing signal. Journal of Banking \& Finance, 21(7), 967-988.

Stein, M., \& Bygrave, W. D. (1990). The anatomy of high-tech IPOs: Do their venture capitalists, underwriters, accountants and lawyers make a difference? In N. C. Churchill, W. D. Bygrave, J. A. Hornaday, D. F. Muzyka, K. H. Vesper \& W. E. Wetzel Jr (Eds.), Frontiers of entrepreneurship research (pp. 394-407). Babson College.

Stoughton, N. M., \& Zechner, J. (1998). IPO-mechanisms, monitoring and ownership structure. Journal of Financial Economics, 49(1), 45-77. http://dx.doi.org/10.1016/S0304-405X(98)00017-8

Strömberg, P. (2007). The new demography of private equity: Swedish Institute for Financial Research. Working Paper.

Sweeting, R. C., \& Wong, C. F. (1997). A UK 'hands off' venture capital firm and the handling of post-investment investor-investee relationships. Journal of Management Studies, 34(1), 125-152. http://dx.doi.org/10.1111/1467-6486.00045

Telser, L. G. (1980). A theory of self-enforcing agreements. The Journal of Business, 53(1), 27-44. http://dx.doi.org/10.1086/296069

Timmons, J. A., \& Bygrave, W. D. (1986). Venture capital's role in financing innovation for economic growth. Journal of Business Venturing, 1(2), 161-176.

Tiniç, S. M. (1988). Anatomy of initial public offerings of common stock. The Journal of Finance, 43(4), 789822. http://dx.doi.org/10.1111/j.1540-6261.1988.tb02606.x

Titman, S., \& Trueman, B. (1986). Information quality and the valuation of new issues. Journal of Accounting and Economics, 8(2), 159-172. http://dx.doi.org/10.1016/0165-4101(86)90016-9

Trotman, K. T. (1996). Research methods for judgment and decision making studies in auditing. Melbourne: Coopers \& Lybrand and Accounting Association of Australia and New Zealand.

Trueman, B. (1994). Analyst forecasts and herding behavior. The Review of Financial Studies, 7(1), 97-124. http://dx.doi.org/10.1093/rfs/7.1.97

Tykvovã, T., \& Walz, U. (2007). How important is participation of different venture capitalists in German IPOs? Global Finance Journal, 17(3), 350-378. http://dx.doi.org/10.1016/j.gfj.2006.05.008

Van Der Geest, R., \& Van Frederikslust, R. A. (2001). Initial returns and long-run performance of private equity-backed initial public offerings on the amsterdam stock exchange. EFMA 2001 Lugano Meetings. SSRN, 269810. http://dx.doi.org/10.2139/ssrn.269810

Van Osnabrugge, M., \& Robinson, R. B. (2001). The influence of a venture capitalist's source of funds. Venture Capital, 3(1), 25-39. http://dx.doi.org/10.1080/13691060117288

Wang, C. K., Wang, K., \& Lu, Q. (2002). Do venture capitalists add value? A comparative study between Singapore and US. Applied Financial Economics, 12(8), 581-588. 
http://dx.doi.org/10.1080/09603100010011963

Welch, I. (1989). Seasoned offerings, imitation costs, and the underpricing of initial public offerings. The Journal of Finance, 44(2), 421-449. http://dx.doi.org/10.1111/j.1540-6261.1989.tb05064.x

Welch, I. (2000). Herding among security analysts. Journal of Financial Economics, 58(3), 369-396. http://dx.doi.org/10.1016/S0304-405X(00)00076-3

Winer, B. J., Brown, D. R., \& Michels, K. M. (1991). Statistical principles in experimental design (3rd ed.). New York: McGraw-Hill.

Wood, D., \& Ross, D. G. (2006). Environmental social controls and capital investments: Australian evidence. Accounting \& Finance, 46(4), 677-695. http://dx.doi.org/10.1111/j.1467-629X.2006.00180.x

Wright, W. F. (1977). Self-insight into the cognitive processing of financial information. Accounting, Organizations and Society, 2(4), 323-331. http://dx.doi.org/10.1016/0361-3682(77)90022-8

Yin, R. K. (2003). Case study research: Design and methods (3rd ed.). Thousand Oaks, CA: Sage Publications.

\section{Notes}

Note 1 . The term attractiveness was adopted as an easily understood construct as a result of pretesting the instrument.

Note 2. In the Australian market the term private equity is commonly used to describe later stage and buyout focused firms. Early stage focused firms are commonly referred to as venture capital firms (AVCAL, 2008).

\section{Appendix A}

\section{Interviewee Profiles}

Subject A was a Senior Investment Analyst specialising in Australian equities with a small to medium sized asset management company who had been in the industry for around six years. His experience of venture capital and private equity backed IPOs was in the valuation of companies mainly coming out of private equity ownership. The size of IPO assessed was ordinarily less than AU $\$ 1$ bn market capitalisation. His experience was not sector specific and included the assessment of IPOs in the mining, data, services and retail sectors.

Subject B was an Equities Analyst with a boutique investment house specialising in Australian equities. He had over 15 years experience in the industry and had worked as both a buy and sell-side analyst. His experience was mainly in the small cap sector.

Subject $\mathrm{C}$ was a founding partner of a funds management company. From an accounting, merchant banking and stock broking background, he had spent the last 15 years in funds management dealing mainly with small and medium cap stocks.

Subject D was a Portfolio Manager with an investment management house. He began his career in banking before moving into broking. His background included around 20 years in broking with small and large broking houses with, latterly, a specialisation in the small cap sector. He has been on the buy-side, with a small cap focus, for 5 years.

Subject E was the Managing Director of an investment company specialising in the small listed company sector. He had been in the industry for nearly 30 years and had experience of both buy and sell sides. The last 15 years had been spent in funds management specialising in small cap stocks.

Subject $\mathrm{F}$ was an Executive Director of a boutique fund management house specialising in small and medium cap companies. He had worked in the funds management industry for the previous ten years, the last eight specialising in the small cap sector.

Subject $\mathrm{G}$ was a Director at a funds management house where he managed a boutique fund focusing on the small cap sector. He had been in funds management for twenty years, the majority of which had been spent specialising in the small cap market.

Subject $\mathrm{H}$ was an Industry Analyst with an investment house specialising in the small and medium cap sector. Subject $\mathrm{H}$ had been dealing in equity markets for over ten years with experience of both the buy and sell-sides. 


\section{Copyrights}

Copyright for this article is retained by the author(s), with first publication rights granted to the journal.

This is an open-access article distributed under the terms and conditions of the Creative Commons Attribution license (http://creativecommons.org/licenses/by/3.0/). 